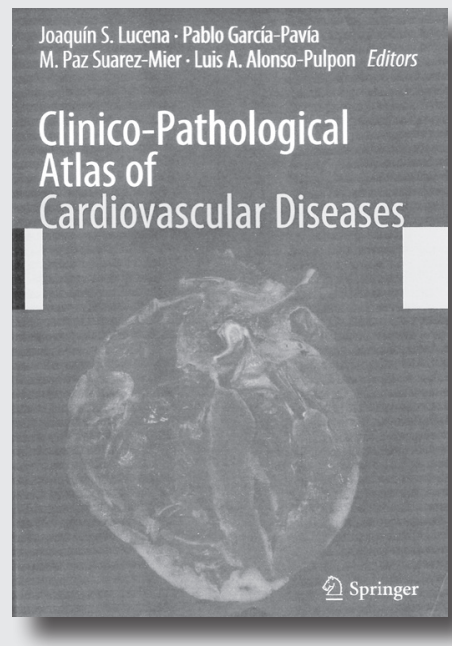

\section{Clinico-Pathological Atlas of Cardiovascular Diseases}

Editores: JS. Lucena, P. García-Pavía, MP. Suárez-Mier y LA. Alonso-Pulpón

Año de edición: 2015

Editorial: Springer, New York
La aparición en esta sección de Cuadernos de Medicina Forense del comentario de este libro supone para la revista una llamada de atención a sus lectores sobre su llegada a la cumbre editorial, alcanzada tras casi dos décadas de trabajo continuado y entusiasta de un grupo de redactores, en el que figuraba desde su fundación este comentarista, a quien le ha llegado el momento de expresar también su satisfacción personal.

El motivo de este autoelogio se justifica por el hecho de que por primera vez, en esta ininterrumpida sección fija de Cuadernos a lo largo de todos estos años, el autor de la obra es un miembro del ahora llamado grupo de editores, y concretamente por su anterior Editor Jefe, Joaquín Lucena, antes y hasta muy recientemente Director de la revista en sus años más difíciles, artífice de su continuidad y creador del moderno formato que actualmente la convierte en la primera publicación periódica de medicina legal en lengua española.

Joaquín Lucena, Jefe del Servicio de Patología Forense del Instituto de Medicina Legal de Sevilla, figura en el siempre importante primer lugar entre los editores del libro, junto con los cardiólogos García Pavía y Alonso Pulpón, del Hospital Universitario Puerta de Hierro, y la histopatóloga Suárez Mier, del Instituto Nacional de Toxicología de Madrid, quienes han dispuesto de la colaboración de otros catorce especialistas de distintos centros del país. Dos prólogos, uno de Valentín Fuster y otro de Gaetano Thiene y Cristina Basso, avalan el nivel ilustrativo y educativo del libro.

La alta información que proporciona el libro ya se deja notar en su título, antes de abrirlo, pues se trata de un Atlas Clínico-Patológico, conjunción no frecuente en este tipo de textos. En él se reúnen doce capítulos que sucesivamente tratan de metodología necrópsica, patologías de la arteria pulmonar, la aorta y el pericardio, coronariopatía arterioesclerótica y no arteriosclerótica, valvulopatías, cardiomiopatías, miocarditis, patología del sistema de conducción y tumores cardiacos. Al pasar sus páginas destacan el número y la calidad de las fotografías, la perfecta organización del texto en distintos apartados y diferentes tipos de letra, y dentro de esto la equilibrada proporción de la iconografía con la explicación textual, y sobre todo, y eso no se nota al leer el libro, pero hay que hacerlo constar, que todas las microfotografías han sido hechas por los autores, lo que significa una intensa búsqueda y una minuciosa recogida de datos en la misma autopsia y con posterioridad a esta.

Resultado de lo anterior, y a lo que damos mayor valor, es la presencia en la obra de imágenes de patología infrecuente, como es el caso de la sarcoidosis, de otras no tan infrecuentes pero difícilmente encontradas en otros atlas, por lo que son prácticamente inéditas, tales como las del sistema de conducción y otras que interesan por su gran actualidad, como acontece con las imágenes de cardiopatías arritmógenas por displasia ventricular derecha que tanta repercusión mediática han empezado a tener por los casos de muerte súbita en deportistas de competición, al ocurrir en una población joven, famosa y de supuesta excelente salud.

El libro, en nuestra opinión, está destinado a tener un gran éxito entre los patólogos clínicos y forenses, y con un significado entre los estudiantes de medicina legal, por ser la autopsia del corazón una de las más difíciles de aprender y en todo caso una importante asignatura pendiente. 